\title{
Financial Liberalization and Fiscal Repression in Turkey: Policy Analysis in a CGE Model With Financial Markets
}

A. Erinc Yeldan, Bilkent University, Ankara, Turkey

\begin{abstract}
The effects of recent Turkish financial liberalization reforms on the real economy are investigated with the aid of a computable general equilibrium model that incorporates financial markets. The model is used for conducting counterfactual and comparative static simulation experiments to analyze three sets of issues: (1) the real side effects of the government's mode of financing its fiscal deficit through debt instruments or monetization; (2) the effects of deregulation of the public debt instrument issuing rules on the financial markets; and (3) the domestic implications of the continued external debt servicing and the foreign exchange rate devaluations. (C) Society for Policy Modeling, 1997
\end{abstract}

\section{INTRODUCTION}

The 1980s have brought profound diversification in the modes of fiscal management for the developing countries, disclosing drastic structural shifts in the interplay of fiscal policy with financial markets. By 1980, many developing countries were used to rely on external sources for public sector deficit financing. However, with the drainage of the sources of external finance and the outbreak of the debt crisis in the early decade, they found themselves in a position where they had to extract resources from the internal

Address correspondence to A. Erinc Yeldan, Bilkent University Department of Economics, 06533, Ankara, Turkey.

A previous version of this paper was presented at the Twelfth Annual Conference of the Middle East Economic Association held in conjunction with the Allied Social Science Associations, New Orleans, January 3-5, 1992.

This research was supported by a grant from the Capital Market Board. The author wishes to acknowledge his indebtedness to Hasan Ersel, Tevfik Nas, Umit Erol, Guven Sak, Merih Celasun, Erol Balkan, Hikmet Ulugbay, and the participants of the seminars at Bilkent, METU, Minnesota, the Capital Market Board, and the Central Bank of the Republic of Turkey for their valuable comments and criticisms; and to Sevdil Ylldirım and Mediha Agar for research and computational assistance. They bear no responsibility, however, for any errors or views expressed in this paper.

Received October 1, 1995; final draft accepted March 1, 1996. 
markets to sustain their fiscal policies. That in turn meant monetization and internal debt accumulation.

Some governments, like those of Chile and Bolivia, managed to cut their deficits through fiscal austerity albeit at significant costs of recession, or they resorted to massive exchange rate depreciations that, along with increased reliance on monetary finance, have led to accelerating inflation rates, capital flight, and diminishing monetary base (World Bank, 1988). Being aware of the inflationary consequences of monetization, many governments applied restrictive monetary policies using the reserve requirement ratio as a policy instrument to extract seignorage revenues. Argentina increased its reserve requirement on demand deposits to more than 70 percent, Brazil to more than 40 percent, and Zaire to 51 percent (World Bank, 1989).

Concurrently, a further source of internal finance has been the domestic commercial banking system, either through forced bond sales at low interest rates, or through high taxes on financial transactions. Monetary contraction under high reserve requirements, coupled with such forced sales of low-interest public securities, however, crowded out the private sector from the financial markets; discouraged financial intermediation; and increased the spread between the deposit and the lending rates. Thus, in spite of advances towards financial liberalization, many developing countries have suffered from undiversified and fragmented capital markets with insufficient returns to financial savings and uncompensated risks (Blejer and Cheasty, 1989). In the face of ad hoc and often contradictionary modes of fiscal finance, these elements led to sporadic financial crises and carried with them an enormous potential for arbitrary wealth redistribution (Diaz-Alejandro, 1985).

Turkey has experienced relatively modest fiscal deficits during the $1980 \mathrm{~s}$, as compared to the experience of many developing nations. However, two additional factors increased the gravity of the problem, hindering the potential gains of liberalization attempts: One was the realization by the fiscal authorities that continued seignorage extraction through monetization was no longer feasible; that is, the Treasury had almost fully exploited the Laffer curve. Thus, the deficit had to be increasingly financed by domestic sources through semiadministrative government bond issues. Secondly, the economy was already experiencing severe inflationary shocks due to the high foreign debt servicing requirements and rapid currency depreciation. These factors combined, 
led to excessively high real interest rates, crowded out private investors, and caused significant strain on the domestic financial markets. In this paper, I examine this changing nature of deficit financing-from direct monetization by way of Central Bank advances, to bond issues to the banking system under nonmarket, administrative policies-on the "deepening" and the efficacy of the domestic financial structures. Specifically, I try to address to the policy dilemmas of deficit financing either through bond sales or monetary advances, and the macro effects of the existing methods of bond financing rules. Further I look at the domestic implications of the external resource transfer problem, which manifests itself due to massive foreign debt servicing and real currency depreciation.

To this end the paper employs a computable general equilibrium model that embodies characteristic elements from both the real and the financial sectors of the Turkish economy. The distinguishing feature of the modeling exercise is that it accommodates financial markets for currency and for credit along with commodityproducing real sectors. The financial side of the model reflects intermediation between the saving funds and financing of physical capital accumulation and of working capital expenses. Further on the real side, it allows for inflationary mark-up pricing rules and disequilibrium adjustment processes in the commodity and factor markets, and incorporates working capital financing of enterprises in a financial environment characterized by the dominance of public assets and high intermediation costs.

The paper is organized under four general sections. In the first, the characteristic nature of the Turkish financial "deepening" and the recent policy reforms towards financial liberalization are discussed. In the second, the technical aspects of the model are presented. The alternative policy options are simulated and studied in the third section, while the last section is reserved for concluding comments.

\section{A. Mode of Turkish Financial Liberalization in the 1980s}

Turkish attempts towards liberalizing its financial system have begun along with the structural adjustment reform program initiated in 1980. Prior to that, the system revealed all attributes of "financial repression" with negative real interest rates, high tax burden on financial earnings, and high liquidity and reserve requirement ratios. Overall, the financial markets have suffered from 
a highly regulated and inefficient banking system, with consequent low-quality portfolio management. Given the underdeveloped and fragmented nature of the capital and stock exchange markets, corporations had to excessively rely on banking credits rather than issuing stocks for financing their working capital balances (OECD, 1988). The fiscal deficits were mostly financed by direct monetization through the Central Bank.

On January 1980, with the introduction of a comprehensive stabilization program, the overall development strategy was reoriented from a regulated and inward-looking system to that of an outward-oriented open economy operating under market incentives. The major elements of the reform program were the switch to a pegged exchange regime of continuous mini adjustments, elimination of price controls and phasing out of subsidies, and the gradual removal of trade restrictions towards full commodity trade liberalization. Many aspects of the Turkish structural adjustment have been well documented in Nas and Odekon (1988); Arıcanlı and Rodrik (1990); Rodrik (1991), and a thorough assessment of the post-Reform performance of the economy can be obtained from there.

In retrospect, it can be stated that the mode and pace of financial reforms have progressed in leaps and bounds, mostly following pragmatic, on-site solutions to the emerging problems. In the beginning, the major aim of the reforms had been the deregulation of the financial system with a naive approach that such deregulation would be sufficient in creating a competitive financial structure functioning efficiently (Ersel, 1991). The first action undertaken was the removal of legal ceilings on deposit interest rates, which led to a fierce struggle among banks and the broker institutions to attract funds from the public. This bonanza of fake "Switzerlandization" was short-lived, however, and came to a halt with the emergence of the 1982 financial crisis, which is extensively narrated in Atiyas (1990).

The foreign exchange regime was liberalized beginning in 1984 . The banks were allowed to accept foreign deposits from citizens and to engage in foreign transactions. Deregulation of restrictions on foreign exchange led to enormous pressures towards currency substitution. Such pressures led to very high real rates of interest throughout the reform period, as the monetary authorities tried to defend the Turkish lira (TL) by increasing the real interest rate to improve the capital account. However, with liberalization of the capital account in 1989, there has been a massive inflow of 
short-term capital into the domestic economy, and as also witnessed under the Southern Cone experience, such use of the interest rate instrument under exchange rate targets led to significant crowding out and was severely deflationary (see, e.g., Dornbusch, 1982; Diaz-Alejandro, 1985).

In the credit market, the Central Bank's control over commercial banks was simplified with a revision of the liquidity and the reserve requirement system. An interbank money market for short-term borrowing facilities was enacted in 1986. In 1987 the Central Bank diversified its monetary instruments by starting open market operations, and in October 1989, it abandoned the use of rediscount facilities as an instrument of selective credit policy. Finally, in early 1990 the Central Bank announced a new monetary program based around a new concept of controlling the stock of its balance sheet both on the assets and liabilities side, which is formulated as the central bank money (CBM). In order to restrain the growth of CBM, the Central Bank signed a protocol with the Treasury to limit public sector borrowing requirements and monetization of the fiscal deficit. Accordingly, the Treasury was granted a credit limit of 3.5 trillion TL ( $9 \%$ of budget revenues for 1991) with a very low interest rate. For borrowings exceeding that amount, market interest rates were to be charged.

In order to regulate and supervise the capital market, a Capital Market Board was established, and it initiated the reopening of the Istanbul stock exchange in 1986. In order to encourage equity financing, significant tax incentives were granted and since 1986, all dividends and capital gains have been exempted from personal taxation.

These measures have had a drastic impact in the domestic economy, and all financial indicators showed trends of financial deepening (see Table 1). However, contrary to expectations, public sector's share in the financial markets remained high. The financing behavior of the corporations did not show significant change, and credit financing from the banking sector and interfirm borrowing continued. Furthermore, the share of private sector securities in total financial assets fell (to $6.3 \%$ in 1988 , as compared to its peak of $10.8 \%$ in 1982; OECD, 1988 , pp. 80-81, and Figure 11). In the meantime, total private debt to the commercial banking system has doubled in real terms (Akyuz, 1990, p. 109). It can thus be argued that in the 1980s private sector financing behavior shifted towards short-term borrowing rather than equity or bond finance. 


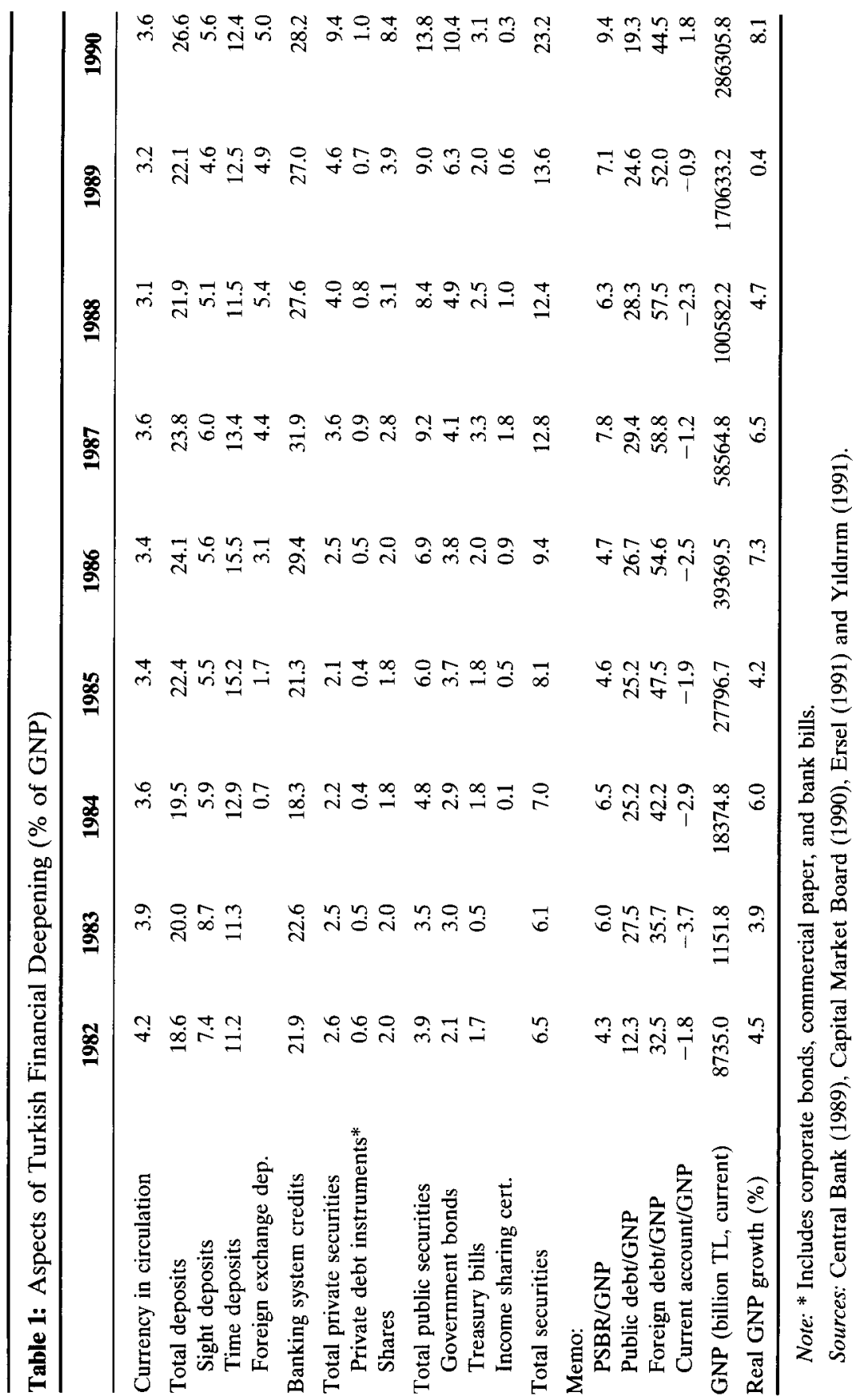


The observed upward trend of the proportion of direct securities to GNP, then, originated from the direct new issues of public sector securities and Treasury bills. Since the commercial banking system has been the major customer of such securities, however, the share of aggregate security instruments has fallen in private portfolios. In fact, with the implementation of positive interest rates, and the new possibility of foreign exchange accounts, the advance of financial deepening for the private households has meant increased foreign exchange deposits with vigorous currency substitution. Thus, it can be stated that the "pioneers of financial deepening" in Turkey in the 1980s have been the public sector securities and the forex deposits.

Table 2 portrays the path of the selected policy instruments and the yields on financial assets throughout the adjustment-cumliberalization period. Although the presented data suggest that private bonds and shares, on the average, have yields higher than the net rate of returns of the public debt instruments, their margin of fluctuation has been very wide and erratic. Consequently, commercial banks have shifted into government debt instruments. As Akyuz (1990, p. 120) attests based on this observation, Turkish experience did not conform to the McKinnon-Shaw hypothesis of financial deepening with a shift of portfolio selection from "unproductive" assets to those favoring fixed capital formation.

\section{B. Patterns of Deficit Financing and Fiscal Repression}

In the early phases of adjustment reforms, Turkish policymakers have achieved substantial success in cutting back the size of the fiscal deficit and the public sector savings gap. As a share of GNP, total real public sector deficit has been reduced to an average of 1.7 percent between 1980 and 1983 (See Table 3), and the public sector borrowing requirement (PSBR) has been pulled to 4.3 percent of the GNP in 1982 (Table 2) from its peak of 10 percent in 1980 (OECD, 1988). There also has been significant improvements in the size of the public savings gap by successful increases of public savings and reductions of consumption out of public disposable income (Celasun, 1990).

In the second half of the 1980s, however, especially after the 1987 civilian elections, indicators of the fiscal authority have eroded severely. The PSBR/GNP ratio rose to 7.8 percent in 1987 , and to 9.4 percent in 1990 . There also occurred major structural changes in the pattern of deficit financing. As data on Table 3 


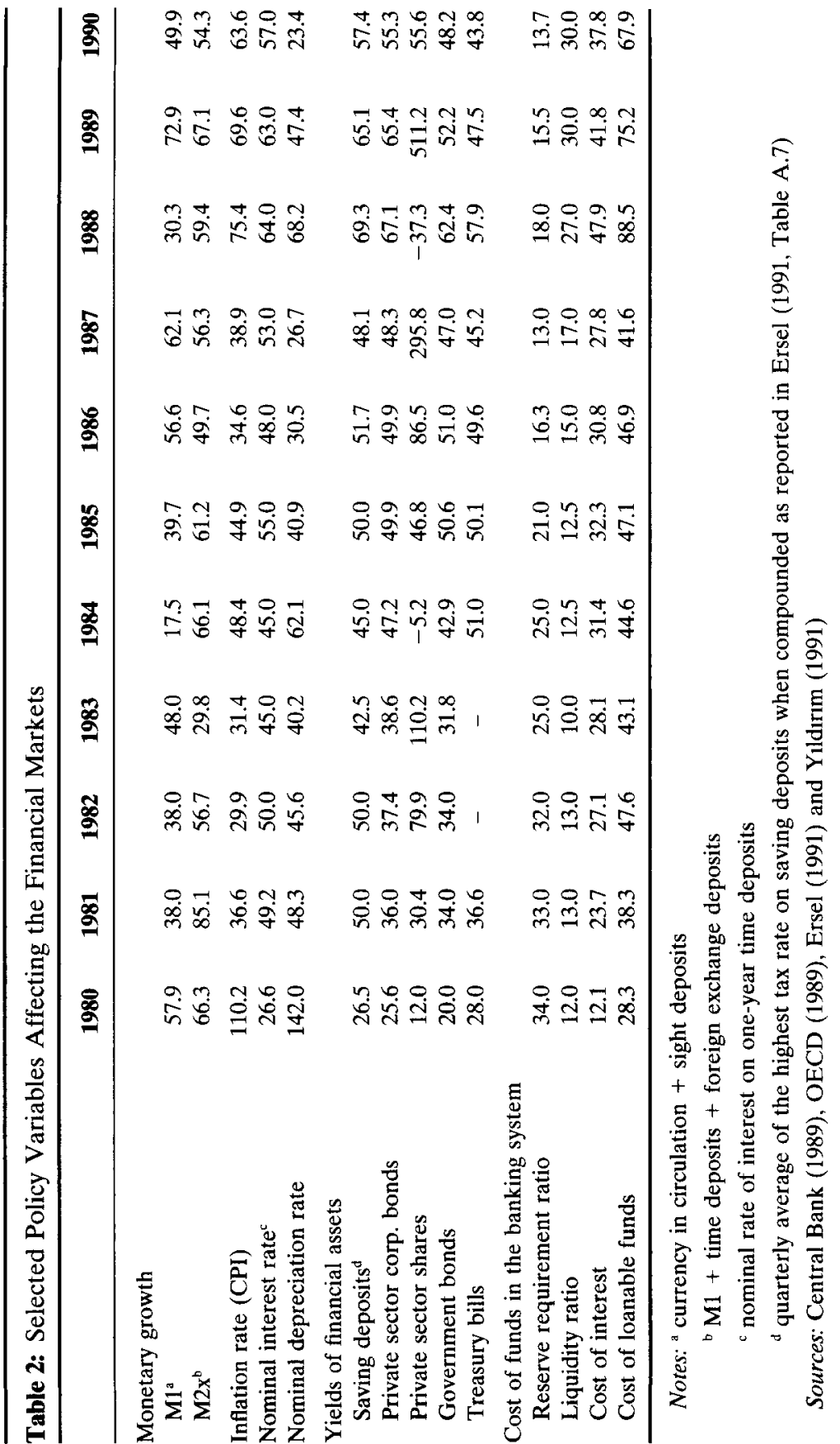




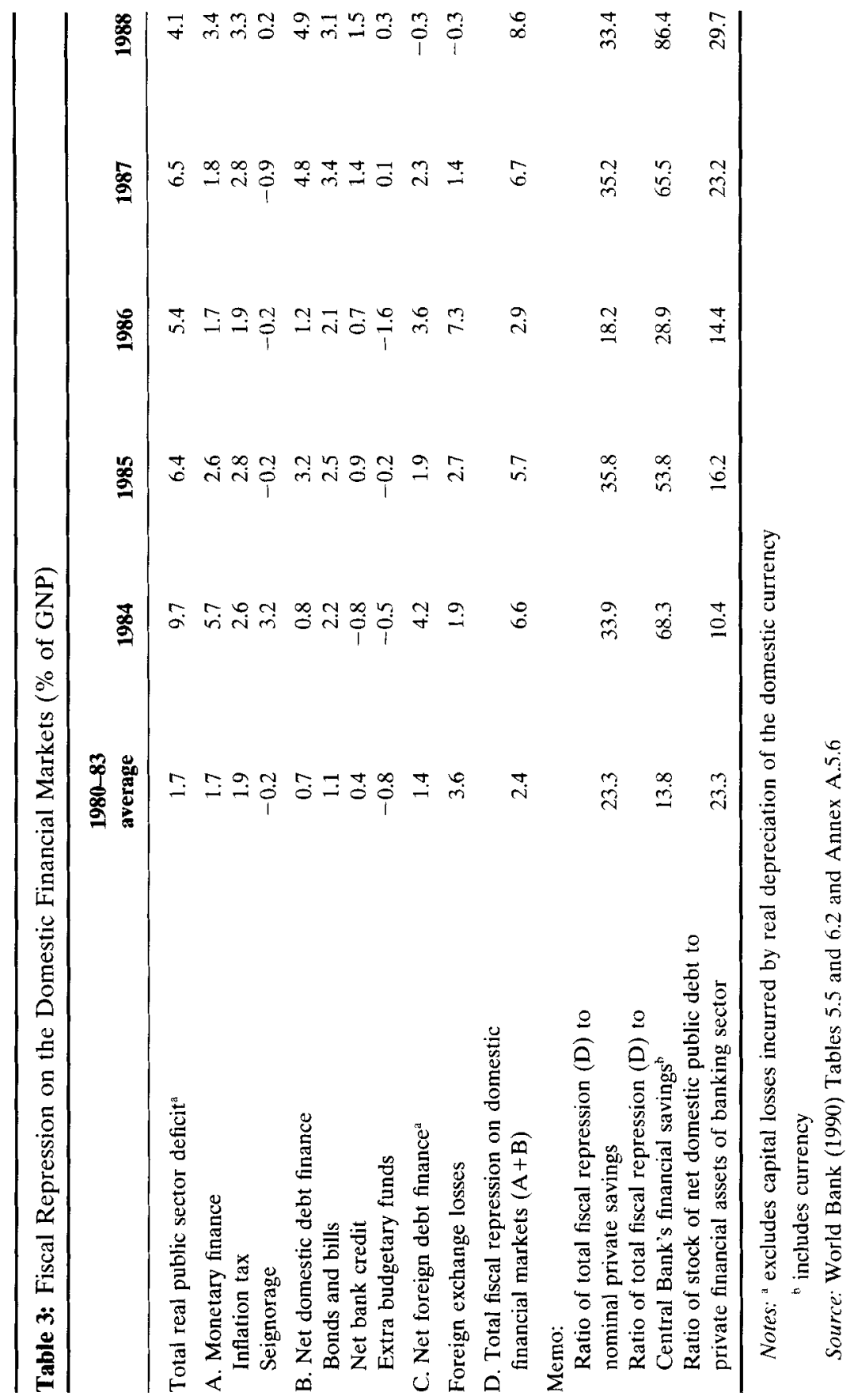


reveal, public sector deficit has been increasingly financed through domestic sources. The share of foreign debt finance has fluctuated, but has been on a downward trend. Within the composition of domestic debt finance, fiscal authorities increasingly relied on bond and Treasury bills as instruments of finance, rather than monetization by direct advances from the Central Bank. Until 1985, almost 60 percent of banknotes has been issued to finance Central Bank's such short-term advances. However, that ratio has declined secularly to reach 20 percent by 1990 (Ulugbay, 1992). Even so, the rate of inflation tax has remained high, and reached to 3.4 percent of the GNP in 1988 (World Bank, 1990).

The government has implemented both market and administrative (nonmarket) mechanisms to transfer resources from the private sector. With the introduction of the auction market for public sector debt instruments in 1986, the government has administered a complex incentive system to finance its fiscal accounts through the domestic financial markets. Government securities have been granted tax exemptions and carried a stable and risk-free net yield close to other types of securities (see Table 2). But the main mechanism that increased their attractiveness for the commercial banking system was that they could be held against the liquidity (disponibility) requirements, and could be used as collateral in the interbank money market. Thus, in many instances the banks have voluntarily chosen to purchase government bonds in addition to the level they are required to hold as disponibility.

Bond financing of the public sector deficit under this mechanism has had several important consequences for the structural evolution of the financial system in Turkey: first, with the secular increase in the disponibility ratio after 1985 , commercial banks were induced to increase the volume of government bonds in their portfolios and they "quasi-automatically became financiers of the fiscal deficit" (OECD, 1988); second, increase in the disponibility ratio has limited the effective control of the Central Bank over monetary expansion, and in general substituted fiscal policy for monetary policy: third, to the extent this substitution was effectively realized, it caused a reduction in the money multiplier, making velocity more volatile and erratic; finally, inducing the bank portfolios in favor of the government bonds rather than loans, it repressed and crowded out the already shallow markets and led to excessive upward pressures on the real interest rates (Ersel, 1991). 
In 1990, the stock of net domestic public debt has reached to almost 30 percent of the private financial assets of the banking sector; and the aggregate fiscal pressures have, according to the World Bank calculations, constituted 33 percent of private savings in nominal terms (see Table 3, and the references therein).

In the next section, I will try to portray the foregoing characteristic aspects of the domestic economy in the CGE modeling framework. Then in the section that follows, the model will be used as a social laboratory to analyze various sets of policy scenarios with respect to financial transactions.

\section{THE CGE MODEL}

The CGE model of the macroeconomy is constructed as a composition of two interdependent real and financial submodels. They are linked through various channels of flows of funds, commercial bank intermediation, and the government's fiscal policy. The real side of the economy can be said to share the common folklore of static macromodeling, which has been laid out in Adelman and Robinson (1978) and in Dervis, Robinson and de Melo, (1982), and is built around four production sectors (agriculture, industry, commerce, and public services), four households (rural, urban labor, industrial, and commercial capitalist), and a government. The rest of the world is aggregated as one broad entity engaging into foreign relations with the domestic economy.

On the financial side, the model shares elements of the so-called "maquette" of Bourguignon, de Melo, and Suwa (1991), which is further summarized in Robinson (1991). Formally it extends the model utilized by Lewis $(1985,1992)$, which studied the structural elements of financial repression using the Turkish experience as an archetype case. The current model recognizes five different sets of actors engaged in portfolio choice and financial activity: households, private enterprises, government, Central Bank, and the commercial banks. Five types of financial assets are specified for interplay in the financial submodel: domestic and foreign currency, public and private bonds, and saving deposits.

The overall model is brought into equilibrium through a Walrasian tatonnement adjustment mechanism based on the endogenous iteration of market prices, the interest rate and the foreign exchange rate to clear the product markets, the credit markets, and the balance of payments. In the labor markets, the wage rates are assumed to be fixed nominally, and thus are cleared through 
quantity adjustments of employment. In industry, the market price is hypothesized to be set by monopolistic producers by downwardrigid markups over variable costs. This specification is implemented in order to capture the high concentration and noncompetitive pricing rules thought to be prevalent in various branches of manufacturing industry (see, e.g., Karaaslan, 1989, and Aksoy, 1982, on evidence of markup pricing behavior in Turkish manufacturing). Boratav (1991) documents further evidence arguing that oligopolistic markups display upward flexibility at times of accelerating inflation, but they tend to be constant during periods of low/ falling inflation rates. Based on Boratav's findings, the model adopts - in the terminology of Gibson, Lustig, and Taylor, (1986)-Kaleckian mechanism of constant markups under periods of price deflation; yet, during inflation, is characterized by the Marx-Sraffian wage-profit trade-off with flexible markups, adjusted upwards by the rate of inflation. Consequently, industrial output supply is determined by aggregate final demand, given the markup-based market price. The possibilities of markup pricing result in both a distorted price structure and income composition favoring profit/rent recipients as discussed extensively in Boratav (1990), and Yeldan (1992). For agriculture and services, given the lack of empirical evidence on market structure, marginal cost pricing rules are assumed along with a neoclassical production function to determine the output supply.

The domestic money market is brought into equilibrium through perturbations of the overall price level, generating inflationary pressures in the domestic economy. Thus, any disequilibrium in either side of the overall model calls for a simultaneous adjustment in both the commodity and the financial markets. Consequently, the model is able to capture an endogenous price inflation story based on structural rigidities and conflicting claims of various social classes for national output.

Since nominal wages are fixed, level of urban employment becomes endogenous, enabling perturbations on levels of output supply. Labor hire decisions of the firms depend upon real wage costs along profit maximization rules. Thus, changes in the price level as aggravated by financial variables may lead to strong nonhomogenous effects on the real side through nominal wage fixity. Accordingly, an important mode of adjustment in the commodity and factor markets can be traced out through a stimulus in aggregate final demand: As pressures build up in the commodity markets, producer prices rise and the demand for money increases 
leading to price inflation. The increase in the price level causes real wages to fall, as wages are fixed nominally. Consequently labor employment, and hence output supply, both increase. This process portrays the classic Keynesian motto: "Output is supplied (labor is demanded) because it is demanded"; in contrast to the (neo)classical motto or the well-celebrated Say's Law: "Output is demanded, because it is supplied." Overall then, the closure of the model is "Keynesian," invoking price and quantity adjustment based on demand-determined production.

On the foreign trade side, the model adopts the traditional treatment of foreign economic relations as utilized in many CGE applications: the Armingtonian commodity system for determining import demand, the constant elasticity of transformation specification in allocation of export and domestic sales, and external closure rules through changes in nominal exchange rate or through endogenous flows of external finance.

The algebraic equations of the model are formally documented in Appendix Table 1. In what follows, I will highlight the important components of the model, referring the interested reader to the formal documentation.

\section{The Financial Sector}

The financial sector of the economy is depicted in Equations 1 through 14 , and an overview can be seen in the balance sheets as portrayed in Figure 1.

Equation 1 states that households' financial wealth in the current period is the sum of previous period's wealth and the flow of current financial savings. Allocation of this wealth into the abovementioned financial assets is achieved via Equations 2-6. Interestbearing saving deposits are assumed to be an increasing function (3) of the real interest rate. Demand for foreign currency is an increasing function (4) of the real exchange rate, but it decreases with respect to the rate of real interest. Domestic currency demand, on the other hand, follows a standard "quantity theory" formulation (5) with velocity being considered as a function of national income and the nominal interest rate. Households' demand for bonds is determined in Equation 6 as an increasing function of the real rate of return on bonds.

The rate of interest is also an important variable adding nonhomogeneity to the real sphere of the macroeconomy, and its role has to be explicitly noted in the households' financial behavior. 
Households

\begin{tabular}{ll}
\hline Assets & Liabilities \\
Domestic currency (M) & Private financial wealth (PFW) \\
Foreign currency (FCUR) & \\
Saving deposits (TDEP) & \\
Government bonds (GBNDH) & \\
Private bonds (PBND) &
\end{tabular}

Commercial Banks

\section{Assets}

Credits to enterprises (LOAN ${ }^{\mathrm{D}}$ )

Gov. bonds held for disponibility

Bonds purchased-voluntary

Required reserves at CB ( $\rho$ TDEP)

\section{Liabilities}

Saving deposits (TDEP)

Enterprises

\section{Assets}

Working capital balances (KW)

Private Investment (DKP)

\section{Liabilities}

Loans from com. banks (LOAN ${ }^{\mathrm{D}}$ )

Private bonds issued (PBND)

Government

Assets

Liabilities

Gov. bonds issued (GBND)

Gov. borrowing abroad (GBOR)

Gov. borrowing from $\mathrm{CB}$ (monetization)

TOTAL: Government's fiscal deficit

Central Bank

\begin{tabular}{ll}
\hline Assets & Liabilities \\
\hline Gov. borrowing from CB & Domestic currenty supply $\left(\mathrm{M}^{s}\right)$ \\
Foreign reserves (FRES) & Required reserves $(\rho \cdot \mathrm{TDEP})$ \\
\hline
\end{tabular}

Figure 1. Financial balance sheets.

Accordingly, aggregate saving decisions of the households depend exclusively on their saving propensities out of their disposable income (Equation 42) following the Keynesian tradition (and the approaches by Lewis, 1985, and Rosenweig and Taylor, 1990), with the interest rate assuming no role in the level of this aggregate. The allocation of the private portfolio, however, is interest sensitive. The real rate of interest plays a further crucial role in the portfolio decision between the domestic and foreign currency substitution. Foreign currency, in this form, is stored entirely for 
"hedging" purposes and serves as ready liquidity, with a rate return of real depreciation in excess of the real rate of interest. In this sense, the real interest rate is considered as an important monetary variable for the Central Bank in controlling the magnitude of foreign currency substitution and runaway from domestic money. Thus, an important channel of upward pressure on the rate of interest recognized in the model is that of the threat of foreign currency substitution as a store of financial wealth.

A further role of the interest rate in the model is that of equalization of the credit funds market (Equation 61). Private enterprises demand credit from the commercial banking sector for financing their private investment expenditures and part of their working capital balances (11). Private investment demand (Equation 9) is in the tradition of Tobin's $q$ formulation (Tobin, 1969), with private investment increasing with respect to the real profit rate and decreasing with respect to the real interest rate. The interest elasticity, $\epsilon$, of private investments is thought to be comparably lower than that of saving deposits, $\psi$, to signify the underdeveloped nature of the credit market and the historically excessive reliance of the enterprises on banking credits in financing their investment decisions (Ersel, 1991). The working capital costs of firms are considered to be determined as a fixed ratio, $k w r$, of total variable costs in Equation 10. An important decision for the private firms is the ratio, $\pi$, of bond financing of their total working capital balances (8). Accordingly, private bonds are issued at the rate $\pi \cdot K W$, and the remainder of the balance is financed by credit loans from the commercial banking sector.

The government's portfolio behavior is also of the same type. Given the fiscal deficit (Equation 41), the government makes a crucial policy decision in its deficit financing either through bond issuing (Equation 7) at the rate $\gamma$, or via direct borrowing from the Central Bank (monetization) (Equation 14). The realization of $\gamma$ has different effects in the macro balances, as the simulation experiments below will attest.

Government's debt instruments are sold almost exclusively to the commercial banking system under both administrative (nonmarket) and market-ridden mechanisms. As discussed extensively in the previous section, commercial banks are granted the option of holding government bonds against their liquidity requirements, $\lambda \cdot T D E P$. Consequently, demand for public bonds by the banks consists of two expressions in Equation 12 to reflect the administrative and market-based components: The first expression is the 
disponibility-related (captive) bond holdings, while the second gives the voluntary bond demand as a function of the real rate of return on bonds, $B R R$. Based on the historical data of realized yields on such risk-free government debt instruments, it is assumed that banks would always be willing to match their disponibility requirements with their purchases of government bonds.

More generally, captive market will be effective only if the rate of return on GDIs is greater than the rate of return on holding money. The constraint becomes totally ineffective if the rate of return on GDIs is higher than the possible investment alternatives. In the former case, which gives the lower threshold, banks will be indifferent between holding GDIs and money as reserves. In the latter case, banks will be willing to hold GDIs not only for reserves but also as investment assets. Hence the constraint becomes ineffective as such voluntary holdings of GDIs increase in bank portfolios.

Total loanable funds are determined as the difference between total saving deposits and bond acquisition in Equation 13. The real rate of interest acts as the equilibrating variable to satisfy Equation 13. In this process, the model captures the effects of financial squeeze emanating from the policy of dumping of the fiscal deficits on the credit markets. As government's bond financing ratio increases, the interest rate is bid up, as a portion of the private financial funds is capitalized by bond financing of the deficit. This process leads to crowding out of the private investment via Equation 9, and deflation of the price level by reducing the liabilities of the Central Bank, and leading to contraction of the domestic currency supply via Equation 14.

The Central Bank acts as the monetary authority regulating the supply of domestic currency and of private credit (Equation 14). In conducting its monetary policy, the reserve requirement ratio, $\rho$, is considered to be the primary tool of the Central Bank. However, not all of the legal reserves are under the control of the Central Bank as the monetary authority, because a portion, $\lambda \cdot T D E P$, of reserves at the commercial banks are held as government securities against their liquidity requirements and in effect can be considered under the control of the Treasury.

The real side of the macroeconomy follows the treatment of the traditional CGE models, and because detailed expositions of these models are available (see, e.g., Adelman and Robinson, 1978; Dervis et al., 1982; Robinson, 1988), discussion here will be brief. Price formation equations are given in the second block of 
Appendix Table 1. Output of agriculture and industry are fully traded, whereas commercial exports are given net of imports due to data limitations.

The market price of industrial output is determined monopolistically through additional markups over prime costs together with conditions of price inflation (Equation 22). The output supply is then demand-determined, and the neoclassical specification of production technology (Equation 23) is omitted for industry. Interest expenses on loans are also cited among the working capital expenses and constitute a significant source of total costs squeezing industrial value added (Equations 19 and 26).

The production technology for the nonindustrial sectors follows a CES specification with limited substitution possibilities among physical capital and labor. Stocks of physical capital are thought to be fixed, leading to upward-sloping supply schedules due to diminishing returns. Further, capital is given as a composite entity, made up of different composition coefficients, $b_{i j}$, across sectors.

A CES function is formulated between the imported and the domestically produced good to obtain the Armingtonian composite (Equation 45). The export supply is determined via the CET specification on Equations 44 and 49. Private consumption demands follow fixed sectoral shares with the assumption that the underlying utility functionals are of the Cobb-Douglas type. Aggregate public consumption (53) and public investment (54) are nominally fixed, leading to financial squeeze as discussed above.

Equations 57 to 62 specify the market clearing conditions in the domestic economy. The commodity markets of the nonindustrial sectors clear via endogenous price movements through the Walrasian tatonnement, whereas the level of industrial output adjusts to quantity demanded as its price is predetermined. In the domestic currency market, the interaction of the real rate of interest with changes in the price level is considered to be the adjusting variable, whereas the balance of payments equilibrium is obtained by endogenous movement of the nominal exchange rate. Bond market clears through forced acquisition of public and private bonds in Equation 60 . The credit market equation (61) is repeated here for convenience, and it merely spells out the banks' portfolio balance of Equation 13. The saving-investment balance of Equation 62 does not actually constitute an independent condition of the system, as the realization of overall macroequilibrium guarantees its satisfaction by Walras' Law. It is, however, imposed as a 
residual check on the behavior of the domestic economy. Determination of equilibria in the financial markets is further depicted in Figure 2.

An important limitation of the model is its static nature. Thus, expectations formation and realizations of capital gains as offered by the arbitrage opportunities are not explicitly admitted for private households. As for the banking sector, it is implicitly assumed that there exists sufficient competitive pressure to equalize the deposit and the credit rates of interest; or alternatively, banks open credits to their "most favored customers" under conditions of zero net profits. Thus, commercial profits originate only in the real sphere and mostly accrue to the commercial capitalist household.

The model is calibrated to 1987 , a year in which the domestic economy is considered to be relatively in macroequilibrium. The selection of the values of key parameters in the base-year is documented in the Appendix Table 2, and the 1987 state of the economy can be read through the first column of Tables 4 and 5 .

\section{GENERAL EQUILIBRIUM INVESTIGATION OF THE FISCAL AND FINANCIAL POLICIES}

In this section, with the aid of the CGE model, we examine analytically the general equilibrium effects of the conduct of fiscal and financial policies to sustain the government's fiscal accounts. The experiments are implemented via time-independent, static perturbations of the policy parameters around their base-run values to capture the macro effects of the historically observed policy maneuvers of the government, and to seek out new policy options. Specifically, the policy scenarios address three distinct but interrelated issues: (1) the macro effects and the policy dilemmas confronted as a result of the government's choice of financing its fiscal deficit either through internal borrowing by bond issues or through direct monetization; (2) the macro effects of the alternative modes of bond financing of fiscal deficit and its repercussions on the financial markets; and (3) the domestic implications of continued foreign debt servicing and of devaluationary policies on the real and financial sectors of the macroeconomy. The policy experiments are carried under four simulation exercises, and are reported sequentially in Tables 4 and 5 . 


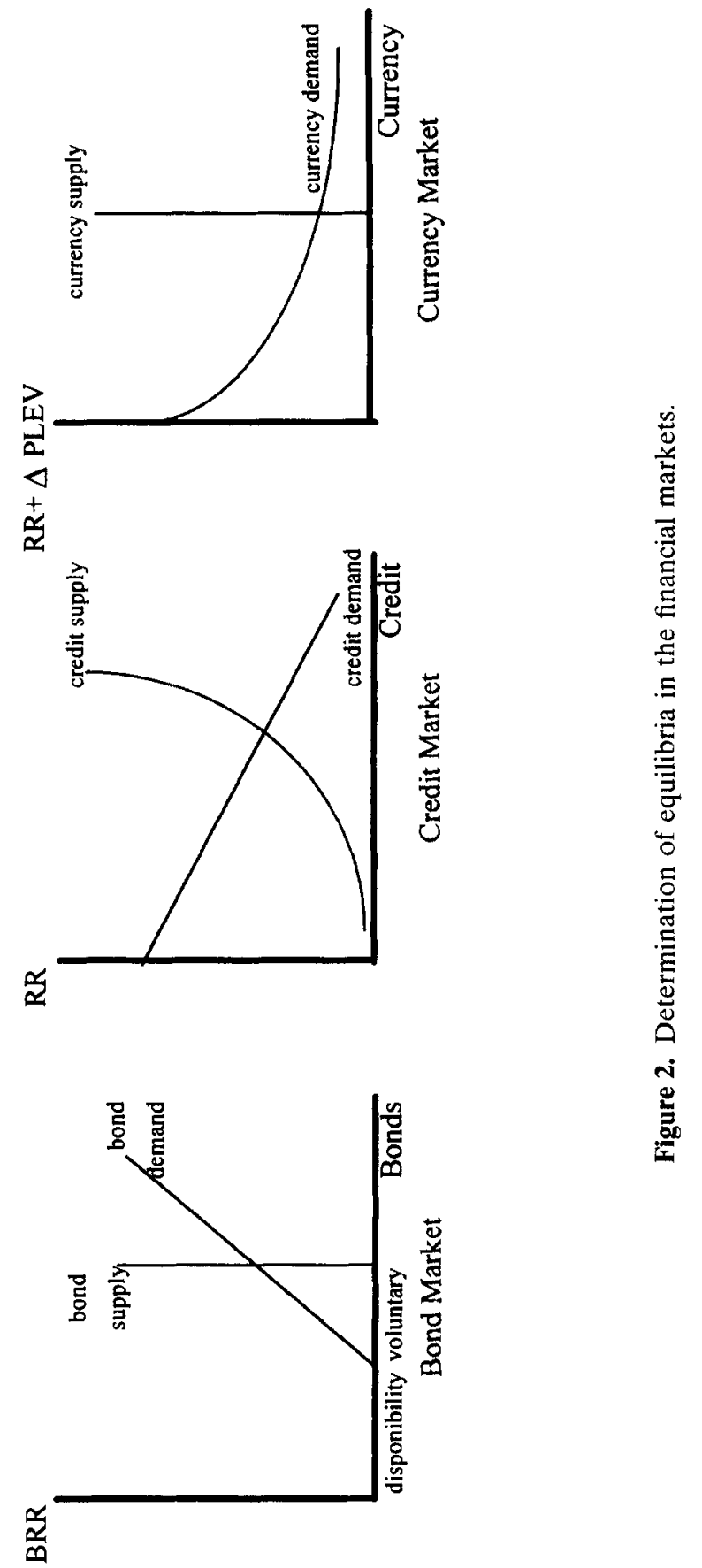


Table 4: Financial Equilibrium of the Domestic Economy (Flow Values in Billion 1987 TL)

\begin{tabular}{|c|c|c|c|c|c|}
\hline & Base run & E1 & $\mathbf{E} 2$ & $\mathbf{E 3}$ & $\mathbf{E 4}$ \\
\hline Price level & 1.000 & 0.977 & 0.999 & 1.011 & 1.049 \\
\hline Real interest rate $(\%)$ & 5.3 & 5.9 & 5.2 & 4.8 & 5.9 \\
\hline Real rate of return on GDIs (\%) & 5.1 & 8.9 & 40.3 & 1.0 & 1.8 \\
\hline Nominal exchange rate (TL/\$) & 856.4 & 845.8 & 855.7 & 858.1 & 883.3 \\
\hline \multicolumn{6}{|l|}{ Public sector fiscal portfolio } \\
\hline Fiscal revenues & 17037.6 & 17457.6 & 17041.3 & 16910.2 & 16824.9 \\
\hline Fiscal expenses & 19992.6 & 20496.8 & 19997.5 & 19841.3 & 19494.6 \\
\hline \multicolumn{6}{|l|}{ Deficit financing } \\
\hline Domestic & 2115.2 & 2188.1 & 2116.9 & 2096.2 & 1842.1 \\
\hline New GDIs issued & 1480.7 & 1969.3 & 1481.8 & 1257.7 & 1289.5 \\
\hline Monetization & 634.6 & 218.8 & 635.1 & 838.5 & 552.6 \\
\hline Gross external borrowing & 839.7 & 851.1 & 839.3 & 834.9 & 827.6 \\
\hline Gross external transfers & 1413.4 & 1432.4 & 1412.7 & 1405.2 & 1741.2 \\
\hline \multicolumn{6}{|l|}{ Private households' portfolio } \\
\hline Aggregate private savings & 9141.5 & 9235.2 & 9144.7 & 9213.2 & 8969.2 \\
\hline Private financial savings & 5485.9 & 5541.1 & 5486.8 & 5527.9 & 5381.5 \\
\hline Stock of financial wealth ${ }^{a}$ & 3447.2 & 3537.0 & 3448.1 & 3420.6 & 3294.1 \\
\hline Savings deposits at banks & 19506.9 & 20270.8 & 19461.2 & 19138.0 & 18924.1 \\
\hline Bonds purchased & 79.0 & 90.7 & 121.9 & 73.4 & 71.9 \\
\hline Domestic currency demand & 18285.7 & 18306.9 & 18296.1 & 18373.4 & 17392.6 \\
\hline Foreign currency demand ${ }^{b}$ & 3991.7 & 4041.7 & 3994.9 & 3984.1 & 3870.2 \\
\hline \multicolumn{6}{|l|}{ Private enterprises' balance sheet } \\
\hline Private investment & 7026.3 & 7047.1 & 7027.8 & 7117.0 & 7127.1 \\
\hline Working capital expenses & 9995.7 & 10209.4 & 9994.2 & 9784.3 & 9538.8 \\
\hline Interest expenses & 522.1 & 587.3 & 511.4 & 464.9 & 558.7 \\
\hline Private bonds issued & 99.9 & 102.1 & 99.9 & 97.8 & 95.4 \\
\hline \multicolumn{6}{|l|}{ Central Bank's balance sheet } \\
\hline $\begin{array}{l}\text { Nominal stock of domestic currency } \\
\text { (end of period) }\end{array}$ & 18285.7 & 17884.9 & 18290.5 & 18575.1 & 18244.8 \\
\hline Loans to treasury (monetization) & 634.6 & 218.8 & 635.1 & 838.5 & 552.6 \\
\hline Required reserves at $\mathrm{CB}$ & 1804.4 & 1875.0 & 1800.3 & 1770.3 & 1750.5 \\
\hline \multicolumn{6}{|l|}{ Commercial banks' balance sheet } \\
\hline Deposits & 19506.9 & 20270.8 & 19461.2 & 19138.0 & 18924.1 \\
\hline GDI holdings & 1501.6 & 1980.7 & 1459.9 & 1282.1 & 1312.9 \\
\hline Captive (disponibility) & 1302.6 & 1694.6 & 0.0 & 1120.1 & 1148.2 \\
\hline Voluntary & 199.0 & 286.0 & 1459.9 & 162.0 & 164.7 \\
\hline Credits to enterprises & 16200.9 & 16415.1 & 16201.1 & 16085.6 & 15860.7 \\
\hline Reserves at CB & 1804.4 & 1875.0 & 1800.3 & 1770.3 & 1750.5 \\
\hline
\end{tabular}

Notes: a Trillion $1987 \mathrm{TL}$

${ }^{b}$ Million \$

E1. Increase Bond Financing of the Fiscal Deficit

E2. Eliminate Captive Bond Sales and Reduce Disponsibility Ratio

E3. Increase Monetization of the Fiscal Deficit

E4. Increase Government External Transfers, Adjustment with Currency Depreciation 
Table 5: Production Employment and Income Generation (Billions 1987 TL)

\begin{tabular}{|c|c|c|c|c|c|}
\hline & Base run & $\mathbf{E 1}$ & $\mathbf{E 2}$ & $\mathbf{E 3}$ & $\mathbf{E 4}$ \\
\hline Real GDP & 58200.9 & 57850.7 & 58205.1 & 58543.4 & 56402.9 \\
\hline \multicolumn{6}{|l|}{ Real output } \\
\hline Agriculture & 14095.8 & 12546.6 & 14067.6 & 14359.3 & 14359.3 \\
\hline Industry & 57613.1 & 58751.4 & 57629.8 & 57147.3 & 53995.9 \\
\hline Commerce & 18450.6 & 18684.7 & 18447.1 & 17839.7 & 18829.3 \\
\hline Public service & 13750.9 & 13672.4 & 13758.4 & 13931.2 & 13022.4 \\
\hline \multicolumn{6}{|l|}{ Employment $^{\mathrm{a}}$} \\
\hline Rural & 9034.9 & 7428.4 & 9003.4 & 9335.0 & 9335.0 \\
\hline Urban & 7184.4 & 7253.6 & 7187.7 & 7163.1 & 7022.8 \\
\hline Agricultural TOT & 100.0 & 91.5 & 101.2 & 102.7 & 93.2 \\
\hline \multicolumn{6}{|l|}{ Total variable costs } \\
\hline Agriculture & 10042.1 & 8563.1 & 10013.4 & 10321.1 & 9909.7 \\
\hline Industry & 41681.1 & 42572.6 & 41674.9 & 40799.6 & 39766.3 \\
\hline Commerce & 8518.5 & 8925.6 & 8519.6 & 7952.7 & 8602.1 \\
\hline Public service & 4986.6 & 5024.8 & 4995.6 & 5139.5 & 4254.1 \\
\hline \multicolumn{6}{|l|}{ Real wage rate } \\
\hline Rural & 0.632 & 0.647 & 0.633 & 0.625 & 0.602 \\
\hline Urban & 1.639 & 1.670 & 1.634 & 1.614 & 1.556 \\
\hline \multicolumn{6}{|l|}{ Real profit rate $(\%)$} \\
\hline Agriculture & 21.2 & 14.6 & 21.1 & 22.3 & 20.9 \\
\hline Industry & 18.1 & 18.4 & 18.1 & 18.9 & 19.6 \\
\hline Commerce & 12.7 & 14.5 & 12.7 & 9.5 & 14.5 \\
\hline Public service & 14.2 & 13.3 & 14.4 & 17.5 & 6.5 \\
\hline \multicolumn{6}{|l|}{ Private disposable income } \\
\hline Rural & 10875.0 & 8764.2 & 10829.3 & 11251.9 & 10858.8 \\
\hline Urban labor & 8096.9 & 8467.3 & 8097.1 & 7805.1 & 7993.4 \\
\hline Industrial capitalist & 12050.9 & 12336.5 & 12049.8 & 12691.5 & 13412.6 \\
\hline Commercial capitalist & 17944.6 & 18804.4 & 17992.3 & 17634.0 & 14840.3 \\
\hline \multicolumn{6}{|l|}{ Public income } \\
\hline Income taxes & 7298.1 & 7522.7 & 7302.0 & 7263.8 & 7164.3 \\
\hline Trade taxes & 2050.4 & 2096.5 & 2049.7 & 2033.0 & 1944.6 \\
\hline Production taxes & 4307.8 & 4327.3 & 4307.1 & 4351.4 & 4406.3 \\
\hline Indirect taxes & 3312.2 & 3440.9 & 3313.4 & 3193.1 & 3241.1 \\
\hline \multicolumn{6}{|l|}{ Consumption demand } \\
\hline Private & 39027.6 & 38328.0 & 39025.9 & 39375.1 & 37348.6 \\
\hline Public & 5308.2 & 5446.8 & 5309.8 & 5267.3 & 5072.3 \\
\hline \multicolumn{6}{|c|}{$\begin{array}{l}\text { Private investment by sector } \\
\text { of destination }\end{array}$} \\
\hline Agriculture & 502.6 & 490.6 & 502.6 & 505.3 & 501.0 \\
\hline Industry & 2071.8 & 2069.7 & 2072.7 & 2081.8 & 2077.7 \\
\hline Commerce & 787.5 & 790.8 & 787.7 & 779.7 & 790.7 \\
\hline \multirow{2}{*}{\multicolumn{6}{|c|}{ Exports ${ }^{\mathrm{b}}$}} \\
\hline & & & & & \\
\hline Agriculture & 792.4 & 797.4 & 792.4 & 789.9 & 799.2 \\
\hline Industry & 8174.9 & 8205.1 & 8175.4 & 8159.9 & 8059.8 \\
\hline \multicolumn{6}{|l|}{ Imports ${ }^{\mathrm{b}}$} \\
\hline Agriculture & 826.4 & 632.5 & 823.0 & 868.2 & 834.6 \\
\hline Industry & 13460.7 & 13686.7 & 13464.3 & 13400.7 & 12932.4 \\
\hline
\end{tabular}

Notes: ${ }^{a} 1000 \times$ person-years

${ }^{\mathrm{b}}$ millions, 1987 U.S.\$

E1. Increase Bond Financing of the Fiscal Deficit

E2. Eliminate Captive Bond Sales and Reduce Disponibility Ratio

E3. Increase Monetization of the Fiscal Deficit

E4. Increase Government External Transfers, Adjustment with Currency Depreciation 


\section{A. Financing of the Fiscal Deficit through Government Debt Instruments}

The first experiment evolves around the government's choice of financing of a given fiscal deficit. Given its deficit, GRDEF, the government finances a portion, $\gamma$, of it by issuing GDIs, and the rest, $(1-\gamma)$, is monetized by direct advances from the Central Bank. As discussed in Section 1 above, in the second half of the decade, Turkish fiscal authorities have increasingly relied on domestic financing of the fiscal deficit through bond issues in contrast to monetary finance.

In Experiment E1, I simulate the macro effects of this policy maneuver by increasing the bond financing rate, $\gamma$, to 0.90 -its historically observed average for 1987-92. The net effects of the experiment follow those classic mechanisms of adjustment to monetary contraction. As the pace of monetization of the fiscal deficit is reduced, supply of domestic currency shrinks (in nominal terms) in the Central Bank's balance sheet (Equation 14). Consequently, domestic price level deflates. In the meantime, in order to sustain its increased sales of bonds, the government finds it necessary to increase the bond interest rate in the bond market. In the banking system, funds are redirected toward acquisition of government bonds, and the cost of credit increases. Private households switch their portfolios towards bonds and deposits to take advantage of the increased returns of these assets. Furthermore, as the exchange rate depreciates in real terms, demand for foreign currency increases as well. This phenomenon puts added pressure on the real rate of interest to rise in order to dampen the switch against the domestic currency.

The effect of price deflation on relative prices is not neutral due to added imperfections on the factor and product markets. Since urban wages have been fixed in nominal terms, real wage costs increase at a time of price deflation. However, as final price is protected in industry by way of downward-fixed markups, increased wage and rental costs are passed on to the consumers. Downward-fixity of the markups in this manner, de facto fixes the relative price of industry against the rest of the economy, and restricts the process of adjustment of the price system, a mechanism that is highlighted in Lewis (1985). Furthermore, the fall in the aggregate price level in the face of protected urban prices causes a downward adjustment in the relative price of agriculture. Terms of trade deteriorate for the rural economy. Commerce, on 
the other hand, booms due to increased rate of return to financial assets, which raises profitability of that sector (Equation 27).

The results of the Experiment E1 highlight many attributes of the adjustment experience of the real sector to financial reforms of the 1980s; deterioration of agricultural incomes, and a heavy transfer of resources to the urban sectors, especially to financial services (Mutlu, 1990; Yeldan, 1994), rapid increases in the share of profits in the industrial sector (Boratav, 1991), increased interest expenditures in industrial value added (Ozmucur, 1991), and hesitant recovery of private fixed investment (Rittenberg, 1991).

\section{B. Reforming the Public Sector Debt Instruments}

Experiment E1 analyzes the policy options of deregulation of public sector dominance in the bond market. Here I simulate an environment where public bonds are offered in a competitive market in which banks no longer claim bonds to sustain their liquidity requirements. Thus, Equation 12 of commercial banks' bond demand now consists of only the voluntary part, being a function entirely of $B R R$. Furthermore, I complement this policy scenario with a significant reduction of the disponibility requirement ratio. Reduction of the liquidity (disponibility) ratio is among the long-stated policy reform suggestions advocated by many outside circles (see, e.g., OECD, 1988); and evidently, with the removal of the disponibility-related (captive) function of GDI holdings, the rationale of keeping the liquidity ratios at their high levels loses much of its justification.

As expected, the real rate of return that has to be offered by the government rises sharply to 40 percent, while the effects on the interest rate remain mixed: First, the increase of the rate of return on GDIs together with the persistent pressures of bond financing of the fiscal deficit prolong contraction of the credit market and tend to push the rate of interest up. However, reduction of the disponibility ratio lowers the overall cost of credit and countervails these pressures, and consequently, changes of the real interest rate over its base-run value remain modest.

Private households now faced with increased yields on bonds direct their portfolios to bond purchases, and the bond market "deepens" to favor private transactors. However, given the static nature of the current model, we cannot study either the feasibility or the long-term consequences of this policy maneuver. Particularly, we were not able to trace out the long-term dynamics of 
debt financing at very high rates of interest. Treasury of our current model has simply chosen to postpone the inflationary pressures, with expected price acceleration in the longer run.

\section{C. Monetization of the Fiscal Deficit}

In the previous experiment, we noted that the surge in the GDI rate of interest may signify a problem in the mode of deficit financing. Thus, the fiscal authority will likely be forced to resort to monetization of the fiscal deficit. To study the effects of this possible move, I conduct Experiment E3 and reduce the value of $\gamma$ in Equations 7 and 14. The results of the experiment reveal the inflationary consequences of such a move, and also highlight the rigidity of the bond market, which operates under the dominance of administrative rules of public securities. As the supply of public bonds recedes, the bond market contracts, and its rate of return falls severely (see Figure 2), while the increased availability of funds in the banking system puts downward pressure on the interest rate.

The gross domestic product booms in the short run as a result of the classic Keynesian mechanisms of monetary expansion. With respect to the relative consequences of this boom, however, qualitatively different results are obtained as compared to the previous experiments: Commercial services contract, terms of trade favor agriculture, and real wages fall. Industry, on the other hand, maintains its profitability due to the asymmetric treatment of oligopolistic markups. The specification of upward-flexible industrial markups protects the position of industrial capital in aggregate value added, and adds a further pressure on price inflation-a route that is discussed extensively in Yeldan (1992).

This experiment highlights the fact that the rate of return on bonds under the current specification is almost entirely supplydetermined, an is very sensitive to public sector's policy decisions. The dominance of the public sector represses the asset markets and causes them to be oversensitive to macroadjustment. The arms-length sale of the bulk of the public debt instruments to the commercial banking system so as to satisfy the liquidity requirements inhibits the role of the rate of return in equilibrating the bond market. Yet, as seen in Experiment E2, liberalization of the bond market by eliminating the captive bond holdings by the banking system results in prohibitively high GDI rates of interest. 
Clearly, the resolution of the dilemma lies in the real sphere of the economy, in the mitigation of the sources of fiscal repression.

\section{D. The Role of External Transfers and Currency Depreciation}

A further constraint in the Turkish financial markets emanates from the external debt servicing requirements. Under Experiment E4, we examine the domestic impact of external resource transfers by way of government's foreign debt repayments and exchange rate devaluation. Since the early phases of its implementation, the international donor agencies have generated quite a conducive environment for Turkish efforts in structural adjustment in terms of SALs, debt relief, and technical aid. In 1980, such aid amounted to a resource transfer of 4.7 percent of GDP into the domestic economy, with Turkey singly accounting for nearly 70 percent of the volume of debt rescheduled internationally by the developing countries in the 1978-80 period (Celasun and Rodrik, 1989). After 1984 , however, especially with the termination of the OECD debt relief, the direction of such transfers was reversed, and Turkey was faced with a pressing need to generate an additional external surplus to service its foreign debt. The ratio of external debt service in aggregate GDP, which stood at 2.4 percent in 1980, has increased to 7.2 percent in 1985 , and stabilized around 80 percent throughout the rest of the decade (OECD, 1988, 1989).

Previous studies conducted by Anand, Chhibber, and van Wijnbergen (1988) argued that external debt is not threatening Turkey's creditworthiness at current levels, and that tighter external policies would lead to a high cost in terms of lost output growth and would have destabilizing consequences for the internal markets.

We study the overall effects of the external resource transfer issue by way of increasing the base-run level of government transfers by 25 percent in U.S. $\$$ terms. We let the domestic economy to adjust externally via currency depreciation.

We observe that the immediate effect of the simulation is a significant depreciation of the nominal exchange rate due to the squeeze of foreign funds in the balance of payments accounts. The real interest rate rises both as a result of the spillover of this effect on the domestic funds, and also as a result of increasing pressures of the threat of currency substitution. With rising import and interest costs, price inflation escalates. The GDP contracts, and real industrial output falls, while commercial services experience a boom due to intensified financial activity as offered by increasing interest rates and currency depreciation. 
With the achieved contraction of GDP, the size of public expenditures, and hence the government's domestic borrowing requirement falls. Consequently, the rate of bond issues reduces with a significant fall in the real rate of return offered in equilibrium.

The impact of currency devaluation is yet another aspect of the external adjustment. Currency devaluation has been an integral part of Turkish structural adjustment reforms since their initiation. Notwithstanding its rapid and unexpected appreciation in 1990-91, pressures on depreciation of the continued, at least in well-settled norms of private expectations. Previous studies on Turkish foreign exchange administration have concluded that prolonged use of the depreciation instrument has had both inflationary and contractionary effects on the domestic economy. Onis and Ozmucur (1990), on the basis of their econometric analysis for instance, have found a spiraling feedback relation of vicious circles "through which the exchange rate effect is rigidly translated into domestic prices and costs and back to the exchange rate" (p. 136). Furthermore, in a similar modeling exercise, Kopits and Robinson (1989) state that in the presence of high fiscal deficits and the pressing need for monetary accommodation under sticky prices and/or inflationary expectations, currency depreciation might lead to an uncontrollable surge in inflation. In their simulations they have found that, based on an unchanged PSBR complemented with a reduced rate of real depreciation during 1981-87, Turkey would have experienced significant success in lowering its inflation rate (by almost $6.5 \%$ less per annum), at a relatively modest cost in terms of potential output foregone (with less than $1 \%$ reduction in real GDP growth). Finally, devaluationary policy has also had the adverse effect on fiscal balances as it increased the domestic currency value of the government's external financial obligations in real terms (Akyuz, 1990).

That prolonged devaluationary policy may have contractionary effects on real output with problematic income distribution consequences is a well-debated issue in the literature (see, e.g., the seminal papers by Diaz-Alejandro, 1963; Krugman and Taylor, 1978; and Taylor, 1983). More recently, Lizondo and Montiel (1989) have formalized several channels of contractionary influence of devaluations that can be succintly summarized as: (1) the relative price effects unfavorable to a large nontraded sector; (2) the real income effects causing a fall in aggregate demand; (3) income redistribution effects that cause an increase in aggregate savings and tend to be contractionary in the short run through 
the Keynesian multiplier mechanisms; (4) supply-side effects due to the increase in costs of intermediate imports; and (5) the real wealth effects causing a reduction in absorption as agents cut back their expenditures in order to replenish their desired real money holdings in the presence of currency depreciation.

The simulation results as reported under Experiment E4 also seem to confirm many of the stagflationary mechanisms cited above, suggesting as well one further route, that of increased interest costs in the presence of the threat of currency substitution. Under the experiment, with the ongoing exchange rate adjustment of 3 percent (in nominal terms), the real interest rate is pushed upwards to maintain the demand for domestic currency. With upward-flexible markups in such an inflationary environment, the model simulates the vicious circle of price inflation-currency depreciation spiral as discussed in Onis and Ozmucur (1990).

Thus the model results suggest that the increased pace of debt servicing in the latter half of the decade has had dire implications for the domestic economy. It has been a significant source of price inflation, has been severely contractionary in the production sphere, and has repressed the fragile bond market.

\section{CONCLUSIONS}

In this paper we tried to investigate the interaction of the real and the financial sectors of the Turkish economy in its different phases of financial liberalization and the alternating modes of deficit financing by utilizing the CGE model as a simulation device. In the context of the Turkish reality, the CGE investigation of the macroeconomy has shown that:

1. The conduct of fiscal policy toward financing the public deficit through bond issuing or monetization has significant diverse effects on real output, employment, and the movement of the interest and the foreign exchange rates;

2. Both the claims of the government on the domestic financial markets and the threat of currency substitution exert upward pressure on the interest rate, causing the financial markets to remain shallow, and leading to contraction of the private investments and real output. The administrative sales of the public debt instruments via captive bond issues to the banking sector inhibit the role of the bond interest rate in equilibrating the asset markets, causing them to be oversensitive to macro adjustment; 
3. There would be strong gains towards private deepening of the financial markets in return to a policy of deregulation of the government's bond financing rules, and reduction in the liquidity ratio for the commercial banking system. However, costs of such a policy maneuver to the fiscal authority seem to be prohibitively high and unsustainable. The remaining alternative of monetization and seignorage, on the other hand, is observed to lead to price inflation and industrial contraction.

4. In an environment such as Turkey of the 1980 s, as characterized by high interest rates on domestic credit, large fiscal deficits and noncompetitive markup pricing rules on output, continued external resource transfers by way of debt servicing and prolonged currency devaluation have had contractionary effects on output and private incomes, and have been severely inflationary. Under such an environment, the method of deficit financing through the domestic financial markets have resulted in a double squeeze of the domestic funds, crowding out and destabilizing the fragile credit markets.

At a more general level, our modeling exercise supports the notion that the general equilibrium attributes of a market economy can be successfully extended to cover both the fiscal and the monetary problems in a consistent fashion. Especially, for the developing economies where the lack of sufficiently long time series data often precludes applications of the econometric techniques, the possibility of utilizing the real financial general equilibrium models based on the calibration techniques may prove very powerful in conducting policy-relevant research.

\section{APPENDIX}

Table A1: Documentation of the CGE Model

This table gives a formal presentation of the CGE model used in the paper. The documentation adheres to the following legend: upper case letters without a bar are endogenous variables; those with a bar denote variables that are treated exogenous. Lower case and Greek letters refer to policy variables or structural parameters. Subscripts $i$ and $j$ refer to sectors, $k$ refers to labor types, and $h$ to household categories. Nonlinear relations are not explicitly spelled out, as their forms are part of the traditional CGE folklore. The $c(\cdot)$ and $d(\cdot)$ refers to the composite and CET functions, and $f(\cdot)$ refers to CES production functions. 
Private Households' Portfolio

$$
\begin{aligned}
\text { PFW }_{1} & =\overline{\text { PFW }}_{\mathrm{t}-1}+\varphi \cdot \mathrm{HHSAV} \\
\mathrm{PFW}_{\mathrm{t}} & =\mathrm{BDEMH}_{\mathrm{t}}+\mathrm{TDEP}_{\mathrm{t}}+\mathrm{FCUR}_{\mathrm{t}}+\mathrm{MDEM}_{\mathrm{t}} \\
\mathrm{TDEP} & =\overline{\mathrm{TD}} \cdot(1+\mathrm{RR})^{\psi} \\
\mathrm{FCUR} & =\overline{\mathrm{FC}} \cdot\left[\frac{(\mathrm{ER} / \mathrm{PLEV})}{(1+\mathrm{RR})}\right]^{\xi} \\
\mathrm{MDEM}_{\mathrm{t}} & =\left[\frac{1}{\overline{\mathrm{V}_{\mathrm{Y}}}+\mathrm{V}_{\mathrm{R}}\left[\mathrm{RR}+\left(\Delta \mathrm{PLEV}_{\mathrm{l}} / \mathrm{PLEV}_{\mathrm{t}-1}\right)\right]}\right] \mathrm{GDP} \\
\mathrm{BDEMH} & =\overline{\mathrm{BDH}} \cdot(1+\mathrm{BRR})^{\eta}
\end{aligned}
$$

\section{Government's Portfolio}

$$
\text { GBND }=\gamma \cdot \text { GRDEF }
$$

Private Enterprises' Portfolio

$$
\begin{aligned}
\operatorname{PBND}_{t} & =\sum_{i} \pi_{i} \cdot \mathrm{KW}_{\mathrm{i}} \\
\mathrm{DKP}_{\mathrm{i}} & =\overline{\mathrm{DK}}_{\mathrm{i}}\left[\frac{(1+\mathrm{RRP})}{(1+\mathrm{RR})}\right]^{\mathrm{\epsilon}_{i}} \\
\mathrm{KW}_{\mathrm{i}} & =\mathrm{kWr}_{\mathrm{i}} \cdot \mathrm{TVC}_{\mathrm{i}} \\
\mathrm{LOAN}^{\mathrm{D}} & =\sum_{\mathrm{i}} \mathrm{PK}_{\mathrm{i}} \cdot \mathrm{DKP}_{\mathrm{i}}+\sum_{\mathrm{i}}\left(1-\pi_{\mathrm{i}}\right) \mathrm{KW}_{\mathrm{i}}
\end{aligned}
$$

\section{Commercial Banks' Portfolio}

$$
\begin{gathered}
\mathrm{BDEMB}=\lambda \cdot \operatorname{TDEP} \cdot(1+\mathrm{BRR})^{\beta_{1}}+\overline{\mathrm{BDB}} \cdot(1+\mathrm{BRR})^{\beta_{2}} \\
(1-\rho-\lambda) \mathrm{TDEP}-\mathrm{BDEMB}=\text { LOAN }^{\mathrm{D}}
\end{gathered}
$$

\section{Central Banks' Portfolio}

$$
M_{t}^{\mathrm{S}}-\mathbf{M}_{\mathrm{t}-1}^{\mathrm{S}}=(1-\gamma) \mathrm{GRDEF}-\rho \cdot \Delta \mathrm{TDEP}+\Delta \mathrm{FRES}_{\mathrm{t}} \cdot \mathrm{ER}
$$

ENDOGENOUS VARIABLES:

$P F W$ : current period private wealth

TDEP : total saving deposits of private households

FCUR : foreign currency demand

$M D E M_{t} \quad$ : demand for domestic currency in the current period

$B D E M H$ : private demand for bonds and securities

$\triangle G B N D_{t}:$ : stock of government bonds issued in the current period

$\triangle P B N D_{t}:$ stock of private bonds issued in the current period

$K W_{i} \quad$ : working capital costs

$D K P_{\mathrm{i}} \quad$ : private investment by sector of destination

$B D E M B$ : bond demand by banks

$\angle O A N^{D}$ : private enterprises' credit demand from the banking sector 
$M_{\mathrm{i}}^{\$} \quad$ : stock of domestic money supply in the current period

$\triangle F R E S$, : foreign reserve accumulation by the central bank

$E R \quad$ : exchange rate (TL/U.S.\$)

$R R \quad$ : real interest rate

$B R R \quad$ : real rate of return on bonds

EXOGENOUS VARIABLES AND PARAMETERS:

$\overline{P F W}_{t-1}$ : previous period private wealth

$T D \quad$ : trend level of saving deposits

$\overline{F C} \quad$ : trend level of foreign currency demand

$\overline{D K}_{i} \quad$ : trend level of private investment

$\overline{B H D}$ : private bond demand shift parameter

$\overline{B D B} \quad$ : banks' bond demand shift parameter

$\overline{P L E V}_{t-1}:$ previous period price level

$M_{t-1}^{S} \quad$ : previous period stock of money supply

$V_{y}, V_{R}:$ parameters of the money demand velocity function

$\varphi \quad$ : ratio of financial savings to aggregate private savings

$\psi \quad$ : interest elasticity of saving deposits

$\xi \quad$ : elasticity of foreign currency demand

$\eta \quad$ : elasticity of private bond demand

$\epsilon_{i} \quad$ : interest elasticity of private investment demand

$\lambda \quad$ : liquidity (disponibility) ratio

$\rho \quad$ : required reserve ratio

$\beta_{1}, \beta_{2}$ : elasticities of captive and voluntary bond demand by banks

$\gamma \quad$ : government bonds issuing rate

$\pi_{i} \quad$ : private bonds issuing rate

$k w r_{i} \quad$ : ratio of working capital costs to total variable costs

\section{Price Formation}

$$
\begin{aligned}
\mathrm{PM}_{\mathrm{i}} & =\overline{\mathrm{PWM}}_{\mathrm{i}} \cdot\left(1+\mathrm{tm}_{\mathrm{i}}\right) \cdot \mathrm{ER} \\
\mathrm{PE}_{\mathrm{i}} & =\overline{\mathrm{PWE}}_{\mathrm{i}} \cdot\left(1+\mathrm{te}_{\mathrm{i}}\right) \cdot \mathrm{ER} \\
\mathrm{PC}_{\mathrm{i}} & =\mathrm{PD}_{\mathrm{i}} \cdot\left(\mathrm{DC}_{\mathrm{i}} / \mathrm{CC}_{\mathrm{i}}\right)+\mathrm{PM}_{\mathrm{i}} \cdot\left(\mathrm{M}_{\mathrm{i}} / \mathrm{CC}_{\mathrm{i}}\right) \\
\mathrm{PX}_{\mathrm{i}} & =\mathrm{PD}_{\mathrm{i}} \cdot\left(\mathrm{DC}_{\mathrm{i}} / \mathrm{XS}_{\mathrm{i}}\right)+\mathrm{PE}_{\mathrm{i}} \cdot\left(\mathrm{E}_{\mathrm{i}} / \mathrm{XS}_{\mathrm{i}}\right) \\
\mathrm{PVA}_{\mathrm{i}} & =\mathrm{PX}_{\mathrm{i}} \cdot\left(1-\mathrm{tn}_{\mathrm{i}}-\mathrm{SIN}_{\mathrm{i}}\right)-\sum_{\mathrm{j}} \mathrm{a}_{\mathrm{ij}} \cdot \mathrm{PC}_{\mathrm{j}} \\
\mathrm{PK}_{\mathrm{i}} & =\sum_{\mathrm{j}} \mathrm{PC}_{\mathrm{j}} \cdot \mathrm{b}_{\mathrm{ji}} \\
\mathrm{PLEV}_{\mathrm{t}} & =\sum_{\mathrm{i}} \omega_{\mathrm{i}} \cdot \mathrm{PD}_{\mathrm{i}}
\end{aligned}
$$

\section{ENDOGENOUS VARIABLES:}

$P M_{i} \quad$ : domestic price of imports

$P E_{i} \quad$ : domestic price of exports

$P C_{i} \quad$ : composite good price

$P X_{i} \quad$ : producer price

$P V A_{i}$ : value added (net) price 
$P K_{i} \quad$ : price of physical capital

$P D_{i} \quad:$ domestic price of the domestic good

$P L E V_{1}$ : price level

EXOGENOUS VARIABLES AND PARAMETERS:

$t m_{i} \quad$ : tariff rate on import

$t e_{i} \quad:$ subsidy rate on export

$t n_{i} \quad$ : indirect tax rate

$a_{i j} \quad$ : input-output (Leontieff) coefficients

$b_{i j} \quad$ : capital composition coefficients

$\omega \quad$ : price level index weights

${\overrightarrow{P W M_{i}}}_{i}$ : world price of imports

$\overline{P W E}_{i}$ : world price of exports

Production and Factor Markets

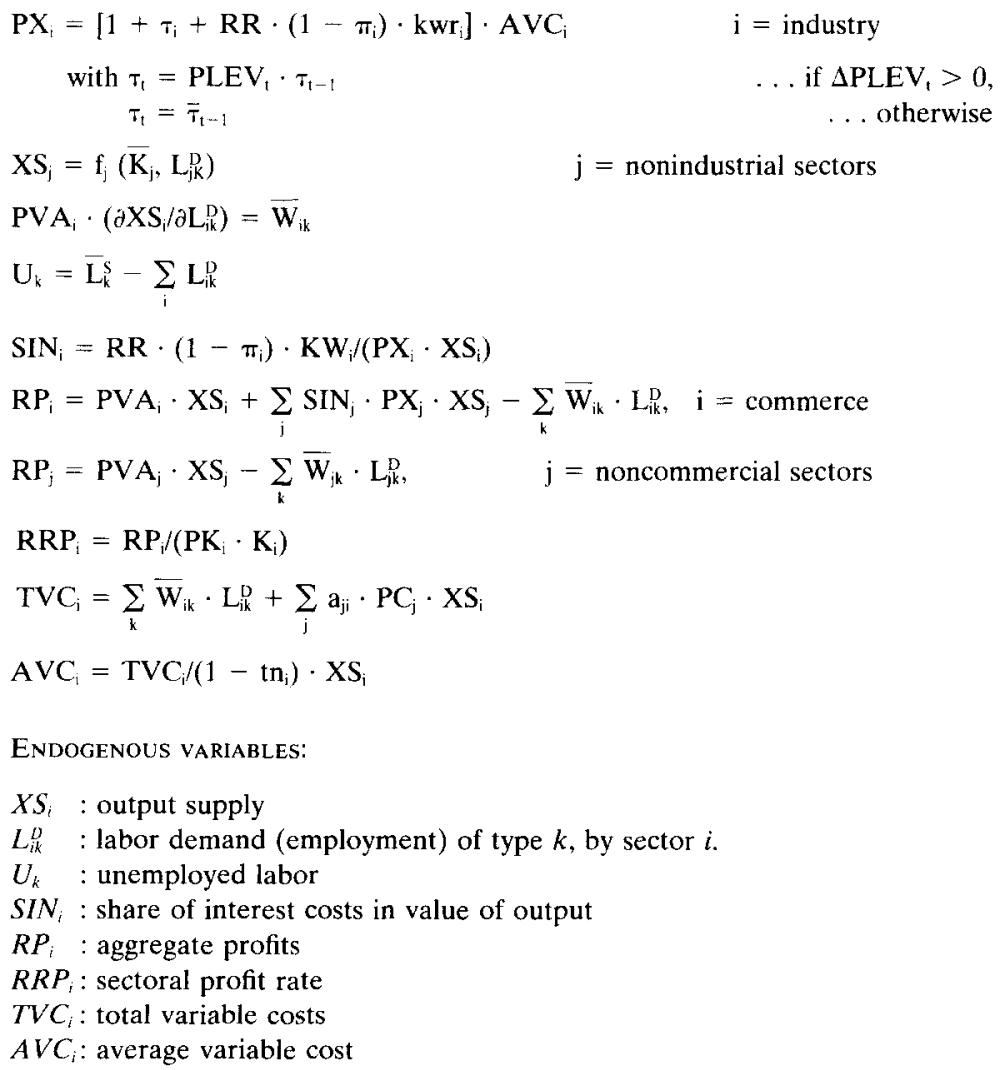

EXOGENOUS VARIABLES AND PARAMETERS:

$\tau_{i}$ : markup rate $\quad(i=$ industry $)$ 
$\bar{K}_{i}$ : physical capital stock

$\bar{W}_{i k}$ : nominal wage rate

$\bar{L}_{k}$ : labor supply

Income Generation and Saving Flow

$$
\begin{aligned}
& \mathrm{YH}_{\mathrm{R}}=\mathrm{PVA}_{\mathrm{A}} \cdot \mathrm{XS}_{\mathrm{A}}+\mu_{\mathrm{R}} \cdot \overline{\mathrm{RM}} \cdot \mathrm{ER}+\overline{\mathbf{T R}}_{\mathrm{A}} \\
& Y_{W}^{H}=\sum_{i} W_{i k} \cdot L_{i k}^{D}+\left(1-\mu_{R}\right) \cdot \overline{R M} \cdot E R+\overline{T R}_{W} \\
& \mathrm{Y}_{\mathrm{K}}^{\mathrm{H}}=\sum_{\mathrm{i} \neq \mathrm{A}} \mathrm{RP}_{\mathrm{i}}+\overline{\mathrm{TR}}_{\mathrm{K}}+\overline{\mathrm{PBOR}} \cdot \mathrm{ER}-\overline{\mathrm{PRTROW}} \cdot \mathrm{ER} \\
& \text { GREV = TARIFF + INDTAX + HHTAX } \\
& \text { TARIFF }=\sum_{i} t_{i} \cdot \overline{\text { PWM }}_{i} \cdot M_{i} \cdot \text { ER } \\
& \operatorname{INDTAX}=\sum_{\mathrm{i}} \mathrm{tn}_{\mathrm{i}} \cdot \mathrm{PX}_{\mathrm{i}} \cdot \mathrm{XS}_{\mathrm{i}} \\
& \text { HHTAX }=\sum_{\mathrm{h}} \mathrm{htx}_{\mathrm{h}} \cdot \mathrm{Yh}_{\mathrm{h}}^{\mathrm{H}} \\
& \text { GREXP }=\overline{\mathrm{GIF}}+\overline{\mathrm{GDTOT}}+\mathrm{EXSUB}+\sum_{\mathrm{h}} \overline{\mathrm{TR}}_{\mathrm{h}}-\overline{\mathrm{GRTROW}} \cdot \mathrm{ER} \\
& \text { EXSUB }=\sum_{i} t_{i} \cdot \overline{\mathrm{PWE}}_{\mathrm{i}} \cdot \mathrm{E}_{\mathrm{i}} \cdot \mathrm{ER} \\
& \text { GRDEF }=\text { GREXP }- \text { GREV }-\overline{\text { GBOR }} \cdot \text { ER } \\
& \text { HHSAV }=\sum_{h} \sigma_{h} \cdot Y_{h}^{H} \cdot\left(1-h t_{h}\right) \\
& \text { GSAV }=\sigma_{G} \cdot \text { GREV }
\end{aligned}
$$

ENDOGENOUS VARIABLES:

$Y_{R, W, K}^{H} \quad$ : total income of rural, worker, and capitalist households, respectively

$G R E V$ : total fiscal revenues of the government

TARIFF : tariff revenues from imports

INDTAX: indirect tax revenues

HHTAX : household income tax revenues

EXSUB : export subsidy payments

$G R E X P$ : total government expenditures

HHSAV: : aggregate private (household) savings

GSAV : aggregate public (government) savings

$G R D E F$ : government's fiscal deficit

\section{EXOGENOUS VARIABLES AND PARAMETERS:}

$\mu_{R} \quad$ : share of remittances accruing to rural households

$h t x_{h} \quad$ : household income tax rate

$\sigma_{h} \quad:$ marginal propensity to save of households

$\underline{\sigma}_{G} \quad$ : public savings ratio

$\frac{R M}{R M} \quad$ : total remittances from abroad

$\overline{T R}_{h} \quad$ : current transfers to households 


\section{$\overline{G I F} \quad$ : aggregate public investment \\ $\overline{G D T O T}$ : aggregate public consumption \\ $\overline{G B O R} \quad$ : public borrowing from abroad \\ $\overline{P B O R} \quad$ : private borrowing from abroad \\ $\overline{G R T R O W}$ : government transfers abroad \\ $\widehat{P R T R O W}$ : private transfers abroad}

\section{Final Demand Generation}

$$
\begin{aligned}
& \mathrm{XD}_{\mathrm{i}}=\mathrm{d}_{\mathrm{i}}\left(\mathrm{DC}_{\mathrm{i}}, \mathrm{E}_{\mathrm{i}}\right) \\
& \mathrm{CC}_{\mathrm{i}}=\mathrm{c}_{\mathrm{i}}\left(\mathrm{DC}_{\mathrm{i}} \mathrm{M}_{\mathrm{i}}\right)=\mathrm{CD}_{\mathrm{i}}+\mathrm{GD}_{\mathrm{i}}+\mathrm{V}_{\mathrm{i}}+\mathrm{ID} \\
& \mathrm{DC}_{\mathrm{i}}=\mathrm{DCR}_{\mathrm{i}} \cdot \mathrm{CC}_{\mathrm{i}} \\
& \mathbf{D C R}_{\mathrm{i}}=\partial \mathrm{c}_{\mathrm{i}}\left(\mathrm{DC}_{\mathrm{i}}, \mathbf{M}_{\mathrm{i}}\right) / \partial \mathrm{DC} \mathrm{C}_{\mathrm{i}} \quad \text { given } \mathbf{P M}_{\mathrm{i}} / \mathbf{P D}_{\mathrm{i}} \\
& \mathrm{M}_{\mathrm{i}}=\partial \mathrm{c}_{\mathrm{i}}\left(\mathrm{DC}_{\mathrm{i}}, \mathrm{M}_{\mathrm{i}}\right) / \partial \mathrm{M}_{\mathrm{i}} \quad \text { given } \mathbf{P M}_{\mathrm{i}} / \mathbf{P D I}_{\mathrm{i}} \\
& E_{i}=\partial d_{i}\left(D C_{i}, E_{i}\right) / \partial E_{i} \quad \text { given } P E_{i} / P_{i} \\
& E_{i}=\bar{E}_{i}\left[\frac{\overline{P W E_{i}} \cdot\left(1+t_{i}\right) \cdot E R}{P D_{i}}\right]^{\delta_{i}} \\
& \mathrm{~V}_{\mathrm{i}}=\sum_{\mathrm{j}} \mathbf{a}_{\mathrm{ij}} \cdot \mathbf{x s _ { \mathrm { j } }} \\
& \mathrm{CD}_{\mathrm{i}}=\left(\mathrm{cd}_{\mathrm{i}} / \mathrm{PC}_{\mathrm{i}}\right) \sum_{\mathrm{h}} \mathrm{Y}_{\mathrm{h}}^{\mathrm{H}} \cdot\left(1-\mathrm{htx}_{\mathrm{h}}\right) \cdot\left(1-\sigma_{\mathrm{h}}\right) \\
& \mathrm{GD}_{\mathrm{i}}=\left(\mathrm{gd}_{\mathrm{i}} / \mathrm{PC}_{\mathrm{i}}\right) \overline{\mathrm{GDTOT}} \\
& \mathrm{DKG}_{\mathrm{i}}=\left(\mathrm{kg}_{\mathrm{i}} / \mathrm{PK}_{\mathrm{i}}\right) \mathrm{GIF}
\end{aligned}
$$

\section{ENDOGENOUS VARIABLES:}

$D C_{i} \quad$ : Armingtonian domestic commodity

$E_{i} \quad$ : exports

$M_{\mathrm{i}} \quad$ : imports

$D C R_{i}$ : share of domestic commodity in the Armingtonian composite

$C C_{i}$ : Armingtonian composite commodity

$C D_{i}$ : private consumption demand

$G D_{i}$ : public consumption demand

$V_{i} \quad$ : intermediate input demand

$D K G_{i}$ : public investment by destination

$I D_{i} \quad$ : aggregate investment demand by sector of origin

$G D P$ : gross domestic product

$X D_{i} \quad$ : aggregate domestic demand

EXOGENOUS VARIABLES AND PARAMETERS:

$\bar{E}_{i}:$ trend level of export demand 
$c d_{i}$ : sectoral share of private consumption demand

$g d_{i}$ : sectoral share public consumption demand

$\mathrm{kg}_{i}$ : sectoral share of public investment by destination

$\delta$ : elasticity of export demand

\section{Domestic Markets Equilibrium Conditions}

COMMODITY MARKETS

$\mathrm{XS}_{\mathrm{i}}=\mathrm{XD}_{\mathrm{i}}$

DOMESTIC CURRENCY MARKET

$\mathbf{M}_{\mathbf{t}}^{\mathrm{s}}=\mathrm{MDEM}_{\mathbf{t}}$

Foreign CuRRenCy market (Balance of Payments)

$\sum_{i} \overline{\text { PWM }}_{i} \cdot M_{i}=\sum_{i} \overline{\text { PWE }}_{i} \cdot E_{i}-\Delta$ FCUR $+\overline{\text { RM }}+\overline{\text { PBOR }}-\overline{\text { PRTROW }}$

$$
+\overline{\text { GBOR }}-\overline{\text { GRTROW }}
$$

BONDS MARKET

$G B N D+\sum_{i}$ PBND $_{i}=B D E M H+$ BDEMB $^{2}$

\section{Credit market}

$(1-\rho-\lambda)$ TDEP - BDEMB $=\sum$ PK $_{i} \cdot \mathrm{DKP}_{\mathrm{i}}+\sum\left(1-\pi_{\mathrm{i}}\right) \cdot \mathbf{K W}_{\mathrm{i}}$

SAVING-INVESTMENT BALANCE

$\sum_{h} \sigma_{h} Y_{h}\left(1-h x_{h}\right)+\sigma_{G}$ GREV $=\sum_{i} P_{K_{i}} \cdot$ DKP $_{i}+$ GIF $+\Delta$ FRES $_{\mathrm{t}} \cdot$ ER 
Table A2: Values of Key Parameters and Policy Instruments in the Base-Year

Private Households' Portfolio

Interest elasticity of saving deposits $(\psi) \quad 2.500$

Elasticity of currency substitution $(\xi) \quad 1.500$

$\begin{array}{ll}\text { Elasticity of bond demand }(\eta) & 1.500\end{array}$

Currency demand function velocity parameters
Income $\left(V_{Y}\right)$

$\begin{array}{ll}\text { Interest rate }\left(V_{R}\right) & 1.132\end{array}$

Banks' Portfolio

share of disponibility-related (captive) GDI holdings $\quad 0.850$

Elasticity of captive GDI holdings $\left(\boldsymbol{\beta}_{1}\right) \quad 3.000$

Elasticity of voluntary GDI holdings $\left(\boldsymbol{\beta}_{2}\right) \quad 4.500$

Government Portfolio

Fiscal debt bond financing ratio $(\gamma) \quad 0.700$

Ratio of government's fiscal deficit to GDP $\quad 0.051$

Enterprise Portfolio

Private bond financing ratio $(\pi)$

Industry $\quad 0.010$

Ratio of working capital balances to total variable costs (kwr)
Industry

Interest elasticity of investment demand $(\epsilon)$
Industry

Central Bank's Portfolio

$\begin{array}{ll}\text { Reserve requirement ratio }(\rho) & 0.093\end{array}$

Price Formation

Average variable costs (AVC)

Agriculture

Industry

0.745

Commerce $\quad 0.492$

$\begin{array}{ll}\text { Public Services } & 0.375\end{array}$

Markup rate ( $\tau)$

Industry

0.335

Tariff rate $(\mathrm{tm})$

$\begin{array}{ll}\text { Agriculture } & 0.091\end{array}$

$\begin{array}{ll}\text { Industry } & 0.173\end{array}$

Indirect tax rate $(\mathrm{tn})$
Agriculture

$\begin{array}{ll}\text { Industry } & 0.029 \\ \text { Comen } & 0.061\end{array}$

$\begin{array}{ll}\text { Commerce } & 0.061\end{array}$

$\begin{array}{ll}\text { Public services } & 0.032\end{array}$

Production and Factor Markets

Elasticity of substitution among capital and labor

$\begin{array}{ll}\text { Agriculture } & 0.500\end{array}$

$\begin{array}{ll}\text { Industry } & 0.400\end{array}$ 
Commerce

Public Services

Share of capital in value added

Agriculture

Industry

0.762

Commerce

0.703

Public Services

0.697

Income Generation and Saving Flow

Income tax rate (htx)

Rural

Urban worker

Urban capitalists

0.135

Production tax rate

0.022

Household saving propensities $\left(\sigma_{h}\right)$

Rural

Urban worker

0.129

Urban capitalist

0.241

Government saving ratio $\left(\sigma_{G}\right)$

0.282

Final Demand Generation

Private consumption sectoral shares $(c d)$

$\begin{array}{lccc} & \text { Rural } & \text { Urban worker } & \text { Urban capitalis } \\ \text { Agriculture } & 0.214 & 0.085 & 0.065 \\ \text { Industry } & 0.551 & 0.657 & 0.622 \\ \text { Commerce } & 0.126 & 0.133 & 0.161 \\ \text { Public services } & 0.109 & 0.125 & 0.152\end{array}$

Public consumption sectoral shares $(g d)$

Agriculture

Industry

Commerce

Public services

Public investment sectoral destination shares $(\mathrm{kg})$

Agriculture

0.079

Industry

0.328

Commerce

0.125

Public services

0.468

Domestic goods-export transformation elasticity

Agriculture

Industry

0.600

Commerce

Domestic goods-import substitution elasticity

Agriculture

Industry

Elasticity of export demand ( $\delta$ )

Agriculture

Industry

Commerce

Ratio of domestic goods in the Armingtonian composite aggregate

Agriculture

Industry

Commerce

1.000

Public services 


\section{REFERENCES}

Adelman, I., and Robinson, S. (1978) Income Distribution Policies in Developing Countries. Stanford University Press.

Aksoy, A. (1982) Structural Aspects of Turkish Inflation 1950-1970. World Bank Staff Papers, No. 540, Washington, DC.

Akyuz Y. (1990) Financial System and Policies in Turkey in the 1980s. In The Political Economy of Turkey: Debt, Adjustment and Sustainability (T. Aricanlı and D. Rodrik, Eds.) New York: Macmillan.

Anand, R., Chhibber, A., and van Wijnbergen, S. (1988) External Balance and Sustainable Growth in Turkey. World Bank, Country Economics Department. Policy, Planning and Research Working Paper No. WPS 86.

Arıcanlı, T., and Rodrik, D. (Eds.) (1990) The Political Economy of Turkey: Debt, Adjustment and Sustainability. New York: Macmillan.

Atiyas, I. (1990) The Private Sector's Response to Financial Liberalization in Turkey: 1980-1982, In The Political Economy of Turkey: Debt, Adjustment and Sustainability (T. Aricanlı and D. Rodrik, Eds.). New York: Macmillan.

Blejer, M.I., and Cheasty, A. (1989) Fiscal Policy and Mobilization of Savings for Growth. In Fiscal Policy, Stabilization and Growth in Developing Countries (M.I. Blejer and K. Chu, Eds.). Washington, DC: International Monetary Fund.

Boratav, K. (1990) Inter-Class and Intra-Class Relations of Distribution under "Structural Adjustment": Turkey During the 1980s. In The Political Economy of Turkey: Debt, Adjustment and Sustainability (T. Arıcanlı and D. Rodrik, Eds). New York: Macmillan.

Boratav, K. (1991) 1980’ li Yıllarda Turkiye' de Sosyal Sinffar ve Bolusum. Istanbul: Gercek Yayinevi.

Bourguignon, F., de Melo, J., and Suwa, A. (1991) Modeling the Effects of Adjustment Programs on Income Distribution. World Development 19(11): 1527-1544.

Capital Market Board (1990) Annual Report. Ankara: Capital Market Board.

Celasun, M. (1990) Fiscal Aspects of Adjustment in the 1980s. In The Political Economy of Turkey: Debt, Adjustment and Sustainability (T. Arıcanlı and Rodrik, Eds). New York: Macmillan.

Celasun, M., and Rodrik, D. (1989) Debt, Adjustment and Growth: Turkey In Developing Country Debt and Economic Performance, Country Studies: Indonesia, Korea, Phillipines, Turkey (J. Sachs, and S.M. Collins, Eds.). Chicago: University of Chicago Press.

Central Bank of the Republic of Turkey (1989) Annual Report. Ankara: Central Bank of the Republic of Turkey.

Dervis, K., Robinson, S., and de Melo, J. (1982) General Equilibrium Models for Development Policy. London: Cambridge University Press.

Diaz-Alejandro, C.F. (1963) A Note on the Impact of Devaluation and the Redistributive Effect. Journal of Political Economy 71: 577-580.

Diaz-Alejandro, C.F. (1985) Good-Bye Financial Repression, Hello Financial Crash. Journal of Development Economics 19:1-24.

Dornbusch, R. (1982) Stabilization Policies in Developing Countries: What Have We Learned? World Development 10(9): 701-708.

Ersel H. (1991) Structural Adjustment: Turkey (1980-1990). Paper presented in the Administrative Staff College Joint Seminar on "Structural Adjustment and Macro Issues," Lahore, October, 26-28, 1991. 
Gibson, B., Lustig, N. and Taylor, L. (1986) Terms of Trade and Class Conflict in a Computable General Equilibrium Model. Journal of Development Studies 23(1): 40-59.

Karaaslan, M.E. (1989) Pricing in the Turkish Non-Agricultural Sector. The Journal of Contemporary Management 3: 42-57.

Kopits, G., and Robinson, D. (1989) Fiscal Policy and External Performance: The Turkish Experience. IMF Working Paper, No. WP/89/20.

Krugman, P., and Taylor, L. (1978) Contractionary Effects of Devaluation. Journal of International Economics 8: 445-456.

Lewis, J. (1985) Financial Liberalization and Price Rigidities in a General Equilibrium Model with Financial Markets. Harvard University Development Discussion Paper No. 211.

Lewis, J. (1992) Financial Repression and Liberalization in a General Equilibrium Model with Financial Markets. Journal of Policy Modeling 14(2): 135-166.

Lizondo, J.S., and Montiel, P.J. (1989) Contractionary Devaluation in Developing Countries. IMF Staff Papers 36(2): 182-227.

Mutlu, S. (1990) Price Scissors in Turkish Agriculture. METU Studies in Development 17(1): 163-212.

Nas, T.F., and Odekon, M. (Eds.) (1988) Liberalization and the Turkish Economy New York: Greenwood Press.

OECD (1988) OECD Economic Surveys: Turkey 1987/88. Paris: OECD Publications.

OECD (1989) OECD Economic Surveys: Turkey 1988/89. Paris: OECD Publications.

Onis, Z., and Ozmucur, S. (1990) Exchange Rates, Inflation and Money Supply in Turkey: Testing the Vicious Circle Hypothesis. Journal of Development Economics 32:133154.

Ozmucur, S. (1991) Prices and Income Distribution. Bogazici University Research Papers, No. ISS/Ec 91-17.

Rittenberg, L. (1991) Investment Spending and Interest Rate Policy: The Case of Financial Liberalization in Turkey. Journal of Development Studies 27: 151-167.

Robinson, S. (1988) Multi-Sector Models of Developing Countries: A Survey. In Handbook of Development Economics, (Hollis, Chenery, and T. Srinivasan, Eds.). Amsterdam.

Robinson, S. (1991) Macroeconomics, Financial variables, and Computable General Equilibrium Models. World Development 19(11): 1509-1525.

Rodrik, D. (1991) Premature Liberalization, Incomplete Stabilization: The Ozal Decade in Turkey. In Lessons of Economic Stabilization and Its Aftermath (M. Bruno, S. Fischer, E. Helpman, N. Liviatan, and L. Meridor, Eds.) Cambridge, MA: The MIT Press.

Rosensweig, J., and Taylor, L. (1990) Devaluation, Capital Flows, and Crowding-Out: A CGE Model with Portfolio Choice for Thailand. In Socially Relevant Policy Analysis (L. Taylor, Ed.). Cambridge, MA: The MIT Press.

Taylor, L. (1983) Structuralist Macroeconomics. New York: Basic Books.

Tobin, J. (1969) A General Equilibrium Approach to Monetary Theory. Journal of Money, Credit and Banking 1: 1-29.

Ulugbay, H. (1992) Evaluation of the 1992 Consolidated Budget. Bilkent University Department of Economics Discussion Paper No. 92-94.

World Bank (1988) World Development Report, 1988. Oxford: Oxford University Press.

World Bank (1989) World Development Report, 1989. Oxford: Oxford University Press.

World Bank (1990) Turkey: A Strategy for Managing Debt, Borrowings, and Transfers under Macroeconomic Adjustment. A World Bank Country Study, Washington, D.C. 
Yeldan, A.E. (1992) Turk Ekonomisinde Yapisal Enflasyon; 1980-1990. Proceedings of the third Izmir Economics Congress, Izmir, June 4-7, 1992.

Yeldan, A.E. (1994) The Economic Structure of Power In Turkey, 1980-1990: Prices, Growth and Accumulation. In Recent Industrialization Experience of Turkey, (F. Senses, Ed.). London: Greenwood Press.

Yıldırım, S. (1991) Turk Mali Kesiminde Bankacılık Sektorunun Gelisimi: 1980-1990. Capital Market Board Research Paper No. AGD/91-20. 